Abstracta Iranica

Revue bibliographique pour le domaine irano-aryen

Volume 25 | 2004

Comptes rendus des publications de 2002

\title{
" The Kangavar Survey - The Iron Age ». IA 37, (2002), pp. 419-436.
}

\section{Rémy Boucharlat}

\section{(2) OpenEdition}

1 Journals

\section{Édition électronique}

URL : http://journals.openedition.org/abstractairanica/4322

DOI : 10.4000/abstractairanica.4322

ISSN : 1961-960X

Éditeur :

CNRS (UMR 7528 Mondes iraniens et indiens), Éditions de l'IFRI

\section{Édition imprimée}

Date de publication : 15 mai 2004

ISSN : 0240-8910

\section{Référence électronique}

Rémy Boucharlat, « «The Kangavar Survey - The Iron Age ». IA 37, (2002), pp. 419-436. », Abstracta Iranica [En ligne], Volume 25 | 2004, document 85, mis en ligne le 15 mars 2006, consulté le 25

septembre 2020. URL : http://journals.openedition.org/abstractairanica/4322 ; DOI : https://doi.org/ 10.4000/abstractairanica.4322

Ce document a été généré automatiquement le 25 septembre 2020.

Tous droits réservés 


\section{" The Kangavar Survey - The Iron Age ». IA 37, (2002), pp. 419-436.}

\section{Rémy Boucharlat}

Outre les résultats que nous livre l'A. sur cette prospection menée en 1974 - en particulier sur l'augmentation de l'occupation à l'âge du Fer III, contemporaine du manor de Godin Tepe - on retiendra ses réflexions méthodologiques et sa prudence sur l'interprétation des données : faut-il voir l'arrivée des Iraniens dans la région dans les changements importants qui interviennent entre l'âge du Bronze et l'âge du Fer I/II ou bien dans ceux qu'on observe entre cette seconde période et l'âge du Fer III ? C'est aussi cette prospection qui amena l'A. à forger le terme Fer IV pour ne pas utiliser la chronologie historique (mède, achéménide, séleucide, parthe) dont les modestes tessons de poterie ne rendent pas compte.

\section{INDEX}

Thèmes : 3.2.2. Pré-Achéménides et Achéménides

\section{AUTEURS}

RÉMY BOUCHARLAT

CNRS - Lyon 